\title{
Solubilization of diabase and phonolite dust by filamentous fungus ${ }^{1}$
}

\author{
Juliana Andréia Vrba Brandão², Maria Leonor Ribeiro Casimiro Lopes-Assad, \\ Sandra Regina Ceccato-Antonini ${ }^{4}$ \\ http://dx.doi.org/10.1590/0034-737X201461050018
}

\begin{abstract}
The objective of this study was to evaluate the effect of the fungus Aspergillus niger strain CCT4355 in the release of nutrients contained in two types of rock powder (diabase and phonolite) by means of in vitro solubilization trials. The experimental design was completely randomized in a $5 \times 4$ factorial design with three replications. It was evaluated five treatments (phonolite dust + culture medium; phonolite dust + fungus + culture medium; diabase powder + culture medium; diabase powder + fungus + culture medium and fungus + culture medium) and four sampling dates $(0,10,20$ and 30 days). Rock dust $(0.4 \% \mathrm{w} / \mathrm{v})$ was added to $125 \mathrm{~mL}$ Erlenmeyer flasks containing 50 $\mathrm{mL}$ of liquid culture medium adapted to A. niger. The flasks were incubated at $30^{\circ} \mathrm{C}$ for 30 days, and analysis of $\mathrm{pH}$ (in water), titratable acidity, and concentrations of soluble potassium, calcium, magnesium, zinc, iron and manganese were made. The fungus A. niger was able to produce organic acids that solubilized ions. This result indicates its potential to alter minerals contained in rock dust, with the ability to interact in different ways with the nutrients. A significant increase in the amount of $\mathrm{K}$ was found in the treatment with phonolite dust in the presence of the fungus. The strain CCT4355 of A. niger can solubilize minerals contained in these rocks dust.
\end{abstract}

Key words: Aspergillus niger, bio-solubilization, rock powder, stonemeal.

\section{RESUMO}

\section{Solubilização de pós de diabásio e de fonolito por fungo filamentoso}

Este trabalho objetivou avaliar o efeito do fungo Aspergillus niger, linhagem CCT4355, na liberação de nutrientes contidos em pós de dois tipos de rocha (fonolito e diabásio), por meio de ensaios de solubilização in vitro. O delineamento experimental foi o inteiramente casualizado, em esquema fatorial $5 \times 4$, com três repetições. Foram avaliados cinco tratamentos (pó de fonolito + meio; pó de fonolito + fungo + meio, pó de diabásio + meio, pó de diabásio + fungo + meio e fungo + meio) e quatro épocas de amostragens $(0,10,20$ e 30 dias). Adicionou-se pó de rocha $(0,4 \% \mathrm{~m} / \mathrm{v})$ a Erlenmeyers de $125 \mathrm{~mL}$, com $50 \mathrm{~mL}$ de meio de cultura líquido adaptado para A. niger. Os frascos foram incubados a $30{ }^{\circ} \mathrm{C}$, por 30 dias, e foram feitas análises de $\mathrm{pH}$ em água, acidez titulável e teores de potássio, cálcio, magnésio, zinco, ferro e manganês solúveis. O A. niger foi capaz de produzir ácidos orgânicos que solubilizaram íons. Este resultado indica o potencial de A. niger para alterar minerais contidos em pós de rocha, com capacidade de interagir de diferentes formas com os nutrientes. Houve aumento significativo da quantidade de K solúvel, no tratamento com pó de fonolito, em presença do fungo. Conclui-se que a linhagem CCT4355 de A. niger pode solubilizar minerais contidos nesses pós de rochas.

Palavras-chave: biossolubilização, Aspergillus niger, pó de rocha, rochagem.

Received: 3/18/2013; Approved: 7/18/2014

${ }^{1}$ Part of the Master's thesis submitted by the first author. Financial support: FINEP and CNPq.

${ }^{2}$ Agronomist, Master of Science. Estrada Outeiro Santos 1867, casa 11, Taquara, 22.713-168, Rio de Janeiro, Rio de Janeiro, Brazil. vrba@uol.com.br

${ }^{2}$ Agronomist, Doctor of Science. Departamento de Recursos Naturais e Proteção Ambiental, Universidade Federal de São Carlos, Campus Araras, Via Anhanguera, km 174, Caixa Postal 153, 13600-970, Araras, São Paulo, Brazil. assad@cca.ufscar.br (corresponding author).

${ }^{3}$ Biologist, Doctor of Science. Departamento de Tecnologia Agroindustrial e Socioeconomia Rural, Universidade Federal de São Carlos, Via Anhanguera, Km 174, Caixa Postal 153, 13600-970, Araras, São Paulo, Brazil. antonini@cca.ufscar.br 


\section{INTRODUCTION}

Brazil has tropical soils formed from different origin matter, often highly weathered, with accelerated removal of nutrients, which eventually promote high acidity and aluminum toxicity, besides the high capacity of phosphorus fixation (Lopes \& Guilherme 2007). However, their low natural fertility can be modified by means of appropriate management techniques for conservation of their physical, chemical and biological characteristics. Noteworthy are the reduction of the intensity of tillage, crop rotation, intercropping cultivation, planting on contour lines, use of mulch, green manure and fertilizer to supply the nutrients demanded for the proper development of plants.

According to the Associação Nacional para Difusão de Adubos - ANDA (National Association for the Promotion of Fertilizers) (2014), Brazil imported more than 21.5 million tons of products to manufacture fertilizers in 2013. Because such fertilizer uses fossil fuel for its processing and transportation, its market value is directly influenced by currency fluctuations and fluctuations in the price of a barrel of oil. Moreover, because they are highly soluble, these fertilizers can be easily leached, both in rainfed agricultural systems as in irrigated systems. Furthermore, soluble fertilizers are not permitted under the current technical standards for organic agriculture, since soil biological activity and water quality must be maintained and incremented in this type of agriculture (Brasil, 1999; FAO, 2007).

Studies have been made in Brazil to alternative sources of nutrients, using organic matter or minerals that have not been commercially exploited due to the lack of knowledge on the potential use, lack of product positioning in the market or lack of interest by the fertilizer industry (Benites et al., 2010). Among these studies, the use of in natura rock powder directly in the soil has been considered of strategic importance for the country since it contributes to the reduction of negative impacts on the Brazilian trade balance, caused by the import of fertilizers (Martins et al., 2008; Nascimento \& Loureiro, 2009).

However, the processes of chemical decomposition of minerals and the release of nutrients from the rock dust to the soil solution, in appropriate way form and amount for plant absorption, are relatively slow. In order to solve this issue, rock dust with finer grain size is searched because the stability of the minerals that compose rocks depends on its structure, its solubility, and its specific surface area among other factors (Kämpf et al., 2009). Promising results have been obtained in experiments with different micro-organisms (filamentous fungi, bacteria and yeasts) capable of promoting the solubilization of rock dust, accelerating chemical modification processes of silicate contained in the dust (Sheng, 2005; Sugumaran \& Janarthanam, 2007; Hamdali et al., 2008; Lian et al., 2008; Xiao et al., 2008).

Saprophytic filamentous fungi present, as part of their metabolic activity, a potent secretory system of acids and enzymes able to solubilize materials and make nutrients available (Grimm et al, 2005; Guebel \& Darias, 2001). Among the ascomycetes filamentous fungi, Aspergillus niger has been extensively used in studies of rock powder solubilization (Lopes-Assad et al., 2006; Lopes-Assad et al., 2010). The biossolubilization promoted by Aspergillus niger occurs in an indirect manner, by the action of reducing acids (citric and oxalic acids), which are produced by the metabolism of the fungus (Mehta et al., 2010) and released into the solution. It is found in leaf litter in the nature and its growth occurs in wide ranges of temperature $\left(0\right.$ to $\left.47^{\circ} \mathrm{C}\right)$ (Schuster et al., 2002).

The objective of this study was to evaluate the effect of the fungus Aspergillus niger, strain CCT4355, on the release of nutrients contained in phonolite and diabase dust by means of in vitro trials.

\section{MATERIAL AND METHODS}

The experiment was carried out in the Laboratory of Agricultural and Molecular Microbiology (LAMAM) and nutrient analysis was performed at the Soil and Plant Chemical Analysis Laboratory, at the Center for Agriculture Sciences of Universidade Federal de São Carlos, Araras Campus in the State of São Paulo.

The phonolite dust was provided by a mining company from Poços de Caldas, State of Minas Gerais, and diabase dust was supplied by a quarry from Araras, State of São Paulo. Both presented median amounts of silica $\left(\mathrm{SiO}_{2}\right)$ (Table 1).

In the solubilization tests, it was used the fungus Aspergillus niger, strain CCT-4355, isolated from sugar cane vinasse (Ceccato, 1989), of the LAMAM microorganism bank. Until the beginning of the tests, the fungus remained stored in the refrigerator $\left(6-8^{\circ} \mathrm{C}\right)$ in test tubes, in MYPG inclined culture medium. Regarding production of inoculum, MYPG medium (3 $\mathrm{g}$ $\mathrm{L}^{-1}$ of meat extract, $3 \mathrm{~g} \mathrm{~L}^{-1}$ yeast extract, $8 \mathrm{~g} \mathrm{~L}^{-1}$ peptone, $10 \mathrm{~g} \mathrm{~L}^{-1}$ glucose and $20 \mathrm{~g} \mathrm{~L}^{-1}$ agar) was used in culture in the test tube in inclined medium; the tubes were incubated at $30^{\circ} \mathrm{C}$ for 5 days. A volume of $4 \mathrm{~mL}$ Tween $80(0.1 \%)$ was added to each culture tube and the spores were scraped with a platinum loop for their release. A suspension from 1.0 to $1.8 \times 10^{7}$ spores $\mathrm{mL}^{-1}$ was obtained, after counting in a Neubauer chamber. For 
setting up the experiment, it was used $50 \mathrm{~mL}$ of the liquid culture medium adapted for $A$. niger $\left(2.85 \mathrm{~g} \mathrm{~L}^{-1}\right.$ sodium citrate, $1 \mathrm{~g} \mathrm{~L}^{-1}$ ammonium phosphate, $0.5 \mathrm{~g} \mathrm{~L}^{-1}$ magnesium sulfate, $0.132 \mathrm{~g} \mathrm{~L}^{-1}$ calcium chloride and $10 \mathrm{~g} \mathrm{~L}^{-1}$ glucose and $\mathrm{pH}$ adjusted to 7.0 ), according to Cerezine et al. (1988). This means that in $50 \mathrm{~mL}$ of culture medium, there was $2.35 \mathrm{mg}$ calcium, $38 \mathrm{mg}$ sodium, $239.5 \mathrm{mg}$ of carbon, $6.08 \mathrm{mg}$ nitrogen, $13.48 \mathrm{mg}$ phosphorus, $5 \mathrm{mg}$ magnesium, $6.65 \mathrm{mg}$ sulfur and $4.2 \mathrm{mg}$ chlorine. The cultivation was performed in 125 -mL Erlenmeyer flasks, with addition or not of $0.2 \mathrm{~g}$ of rock dust $(0.4 \% \mathrm{w} / \mathrm{v})$, with particle size smaller than $0.053 \mathrm{~mm}$ (270 mesh) and inoculation or not of $0.5 \mathrm{~mL}$ of the spore suspension, according to the treatment.

The in vitro experiment was carried out in a completely randomized design in a $5 \mathrm{x} 4$ factorial design with three replications. The treatments were as follows: A. niger + medium (MA); phonolite dust + medium (FM); phonolite dust + A. niger + medium (FMA); diabase dust + medium $(\mathrm{DM})$ and diabase dust + A. niger + medium (DMA). The flasks were incubated at $30^{\circ} \mathrm{C}$, $160 \mathrm{rpm}$, for 30 days, with four sampling times $(0,10$, 20 and 30 days). The contents of the flasks were filtered under vacuum, using no. 1 Whatman filter paper. The following were analyzed in the filtrate: water $\mathrm{pH}$ and titratable acidity by samples titration up to $\mathrm{pH} 7$, using $\mathrm{NaOH} 0.05 \mathrm{~mol} \mathrm{~L}^{-1}$ were analysed in the filtrate. Contents of potassium $(\mathrm{K})$ were determined by flame emission photometry and contents of soluble calcium $(\mathrm{Ca})$, zinc $(\mathrm{Zn})$, manganese $(\mathrm{Mn})$ and iron $(\mathrm{Fe})$ by atomic absorption spectrophotometry.

The results of in vitro tests were submitted to analysis of variance (F test) and means were compared by Tukey test at $5 \%$ probability or by regression depending on the origin of the data, quantitative or qualitative, using the statistical software Statistica 6.0 (2001).

\section{RESULTS AND DISCUSSION}

The phonolite rock dust in the presence of the fungus provided greater amount of solubilized K (Table 2); however, the action of $A$. niger on the diabase rock powder did not provide significant difference in the amount of solubilized $\mathrm{K}$. The amount of $\mathrm{K}$ from the phonolite rock dust is ten times greater than that of diabase rock dust (Table 1), which explains the result obtained in phonolite + medium + fungus treatment (AMF), which had a high release of the soluble $\mathrm{K}$ into the medium, demonstrating the solubilizing potential of the fungus.

Potassium present in feldspars is not readily available because it is strongly bound to oxygen molecules of tetrahedrons of $\mathrm{SiO}_{4}$ and $\mathrm{AlO}_{4}$ (Curi et al., 2005). Therefore, the release of $\mathrm{K}^{+}$ions requires the dissolution of feldspars, by the action of $\mathrm{H}^{+}$ions from the acids produced by $A$. niger. The reaction can be expressed in a simplified way, as $\mathrm{KAlSi}_{3} \mathrm{O}_{8}+\mathrm{H}^{+} \rightarrow \mathrm{HAlSi}_{3} \mathrm{O}_{8}+\mathrm{K}^{+}$.

Contents of $\mathrm{Ca}$ were higher in treatments with rock powder, without the presence of fungus, with no difference between the two types of dust (Table 2), indicating a likely intake by the fungus. This is because $\mathrm{Ca}$ silicates and aluminosilicates are sufficiently solube in low $\mathrm{pH}$, but the concentration of soluble $\mathrm{Ca}$ decreases as pH increases (Mello \& Perez, 2009). The small amounts of $\mathrm{Ca}$ found in the treatment with phonolite rock dust, which showed no calcium oxide in its composition (Table 1), can be explained by the addition of calcium chloride in the culture medium.

The fungus $A$. niger had no effect on the solubilization of $\mathrm{Mg}, \mathrm{Zn}, \mathrm{Fe}$ and $\mathrm{Mn}$ in the treatments with both studied rock dust (Table 2), and the amount of solubilized Fe was higher in diabase rock dust treatment. Phonolite is an alkaline leucocratic rock whereas the evaluated diabase (geologically classified as a lati-andesite) is a basic mesocratic rock (Machado et al. 2005), a reflex of the mafic mineral contents that have dark color since they contain iron, magnesium, titanium, manganese, and so on. The iron content of the diabase rock was higher than that of the phonolite rock (Table 1). Therefore, the amount of that ion in the medium was higher in the diabase + medium + A. niger (DMA) treatment than in the phonolite + medium $+A$. niger (FMA) treatment.

Significant results at $5 \%$ of probability were found in the time and treatment interaction, for all attributes, except for $\mathrm{pH}$ and titratable acidity, which showed high variance. Data regarding treatments with diabase $+A$. niger + medium (DMA) and phonolite dust + A. niger + medium (FMA) are discussed in this paper.

The levels of soluble Ca (Figure 1A) decreased until the twentieth day of the trial; after this period, the concentration of $\mathrm{Ca}$ increased, but this increase was not

Table 1. Chemical characterization of phonolite and diabase dust used in in vitro solubilization trial

\begin{tabular}{|c|c|c|c|c|c|c|c|c|c|}
\hline \multirow{2}{*}{ Rock dust } & $\mathrm{SiO}_{2}$ & $\mathrm{Fe}_{2} \mathrm{O}_{3}$ & $\mathbf{K}_{2} \mathbf{O}$ & $\mathrm{Al}_{2} \mathrm{O}_{3}$ & $\mathrm{Na}_{2} \mathrm{O}$ & MgO & $\mathrm{CaO}$ & $\mathrm{TiO}_{2}$ & $\mathrm{MnO}$ \\
\hline & \multicolumn{9}{|c|}{$\%$} \\
\hline Phonolite $^{1}$ & 54.8 & 3.29 & 8.46 & 21.3 & 6.07 & - & - & - & - \\
\hline Diabase $^{2}$ & 50.31 & 12.62 & 0.84 & 13.94 & 2.24 & 6.91 & 10.16 & 1.02 & 0.19 \\
\hline
\end{tabular}

${ }^{1}$ Supplied by minning company Curimbaba Ltda; ${ }^{2}$ Supplied by Acme Analytical Laboratories LTD. 
due to the action of $A$. niger (Table 2). This behavior is in part due to the consumption of this element by the microrganism, in part due to the presence of organic acids produced by $A$. niger, especially citric acid $\left(\mathrm{C}_{6} \mathrm{H}_{8} \mathrm{O}_{7}\right)$, which presents a chelating activity by $\mathrm{Ca}^{+2}$ (Carvalho et al., 2005).

The content of potassium showed an increase, over time, not reaching its maximum value (Figure 1B) being much more expressive in phonolite dust, richer in $\mathrm{K}_{2} \mathrm{O}$ than diabase dust (Table 1). After 30 days, it was found that the amount of $\mathrm{K}$, solubilized by A. niger, in the treatment with phonolite dust + medium + fungus (FMA) has not reached its maximum degree (Figure 1B). Because each flask with phonolite dust contained 7.2 $\mathrm{mmol}_{\mathrm{c}} \mathrm{dm}^{-3} \mathrm{~K}$, the content of soluble $\mathrm{K}$, after 30 days of incubation, was $1.21 \mathrm{mmol}_{c} \mathrm{dm}^{-3}$ in the phonolite + medium + fungus treatment. This corresponds to a solubilization rate of $16.8 \%$ whereas this rate remained at $7.2 \%$ in the medium + phonolite treatment. Using the same strain of A. niger, Lopes-Assad et al. (2006) obtained solubilization rates of $54.7 \%$ for the alkaline ultramafic rock dust, containing $3.32 \%$ of $\mathrm{K}_{2} \mathrm{O}$ and $33.26 \% \mathrm{SiO}_{2}$, and $11.8 \%$ for phlogopitite dust, containing $5.13 \%$ of $\mathrm{K}_{2} \mathrm{O}$, and $47.12 \% \mathrm{SiO} 2$ at 21 days of incubation. These results suggest that the rate of solubilization obtained with $A$. niger is probably related to the amounts of $\mathrm{SiO}_{2}$ and $\mathrm{K}_{2} \mathrm{O}$, present in rocks and their mineralogical characteristics.

The behavior of ion $\mathrm{Mg}$ (Figure 2A) in the treatments with diabase dust was similar to the behavior presented by $\mathrm{Ca}$, with a decrease in the content until day 20 , probably due to consumption by the microorganism, and a subsequent increase in which it was not possible to state that the maximum solubilization was reached at the end of the trial. The behavior of the ions $\mathrm{Zn}, \mathrm{Fe}$ and $\mathrm{Mn}$ in the treatments with diabase rock dust was similar over the 30 days of the trial (Figures 2b, c and d), with greater release between the tenth and twentieth day of the trial.
Fungus $A$. niger releases reducing acids (citric and oxalic acids), which convert the insoluble forms Fe (III) and $\mathrm{MnO}_{2}$ into soluble forms Fe (II) and Mn (II) (Mehta et al., 2010). Some factors have an influence in the submerged fermentation of citric acid (type and

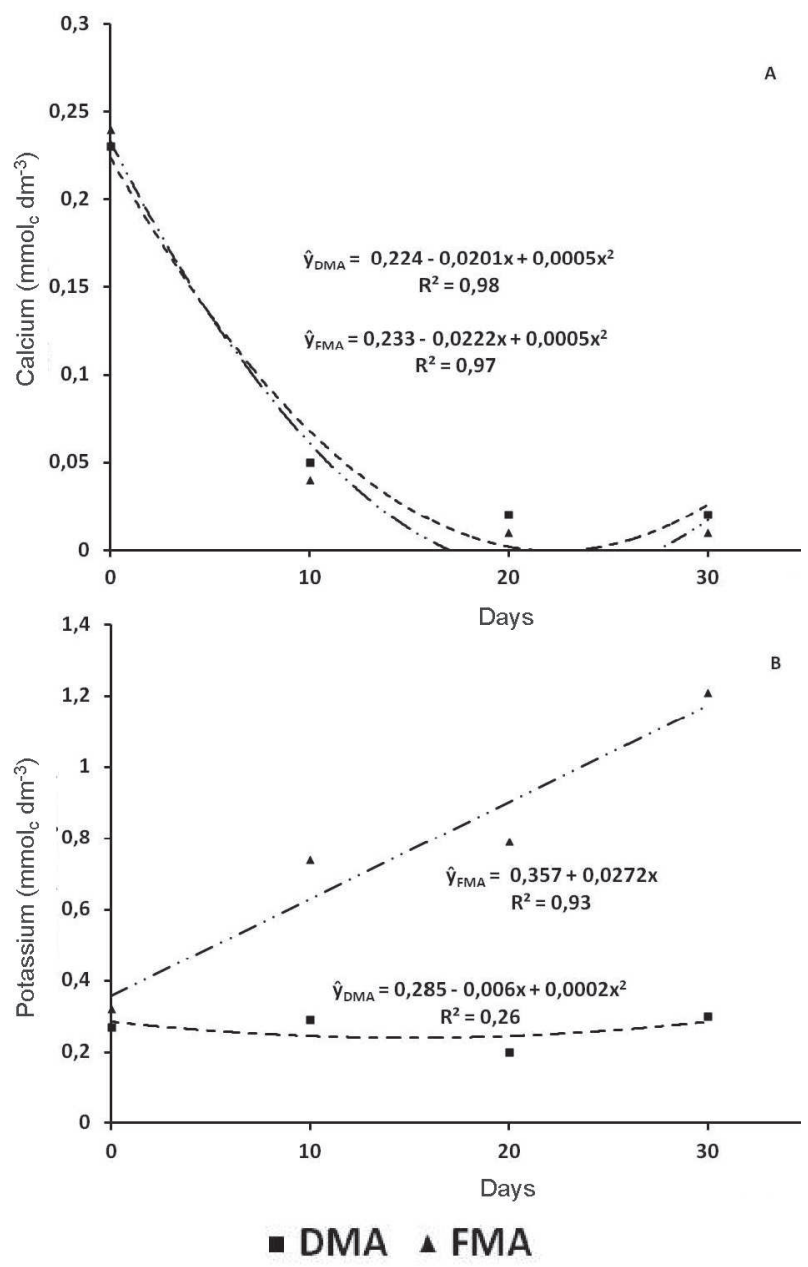

Figure 1. Variation in the concentration of calcium (A) and potassium (B) over 30 days of solubilization trials of diabase dust (DMA) and phonolite dust (FMA) using Aspergillus niger in liquid culture medium.

Table 2. Chemical characteristics determined at 30 days of in vitro trials of solubilization of phonolite and diabase dust by the fungus Aspergillus niger strain CCT4355

\begin{tabular}{lccccc}
\hline \multirow{2}{*}{ Characteristics } & \multicolumn{3}{c}{ Treatments } \\
\cline { 2 - 6 } & DM & DMA & FM & FMA & MA \\
\cline { 2 - 6 } pH & $6.64 \mathrm{~b}$ & $7.15 \mathrm{a}$ & $6.71 \mathrm{~b}$ & $5.95 \mathrm{c}$ & $3.53 \mathrm{~d}$ \\
Titratable acidity $\left(\mathrm{mmol}_{\mathrm{c}} \mathrm{dm}^{-3}\right)$ & $2.76 \mathrm{bc}$ & $1.00 \mathrm{c}$ & $2.00 \mathrm{c}$ & $8.16 \mathrm{~b}$ & $52.00 \mathrm{a}$ \\
Potassium $\left(\mathrm{mmol}_{\mathrm{c}} \mathrm{dm}^{-3}\right)$ & $0.36 \mathrm{c}$ & $0.26 \mathrm{c}$ & $0.50 \mathrm{~b}$ & $0.77 \mathrm{a}$ & $0.30 \mathrm{c}$ \\
Calcium $\left(\mathrm{mmol}_{\mathrm{c}} \mathrm{dm}^{-3}\right)$ & $0.29 \mathrm{a}$ & $0.08 \mathrm{~b}$ & $0.26 \mathrm{a}$ & $0.08 \mathrm{~b}$ & $0.06 \mathrm{~b}$ \\
Magnesium $\left(\mathrm{mmol}_{\mathrm{c}} \mathrm{dm}^{-3}\right)$ & $0.39 \mathrm{a}$ & $0.33 \mathrm{a}$ & $0.38 \mathrm{a}$ & $0.35 \mathrm{a}$ & $0.38 \mathrm{a}$ \\
Zinc $\left(\mathrm{mg} \mathrm{dm}^{-3}\right)$ & $0.19 \mathrm{a}$ & $0.21 \mathrm{a}$ & $0.13 \mathrm{bc}$ & $0.16 \mathrm{ab}$ & $0.09 \mathrm{c}$ \\
Iron $\left(\mathrm{mg} \mathrm{dm}^{-3}\right)$ & $64.40 \mathrm{a}$ & $64.47 \mathrm{a}$ & $12.25 \mathrm{bc}$ & $16.77 \mathrm{~b}$ & $9.37 \mathrm{c}$ \\
Manganese $\left(\mathrm{mg} \mathrm{dm}^{-3}\right)$ & $287 \mathrm{a}$ & $2.21 \mathrm{ab}$ & $2.58 \mathrm{ab}$ & $2.41 \mathrm{~b}$ & $0.12 \mathrm{c}$ \\
\hline
\end{tabular}

$\mathrm{DM}=$ diabase dust in liquid culture medium; DMA = diabase dust and A. niger in liquid culture medium; FM = phonolite dust in liquid culture medium; FMA $=$ phonolite dust and $A$. niger in liquid culture medium; MA = A. niger in liquid culture medium. Means on the lines, followed by an equal letter at least, do not differ by Tukey test at $5 \%$ probability 

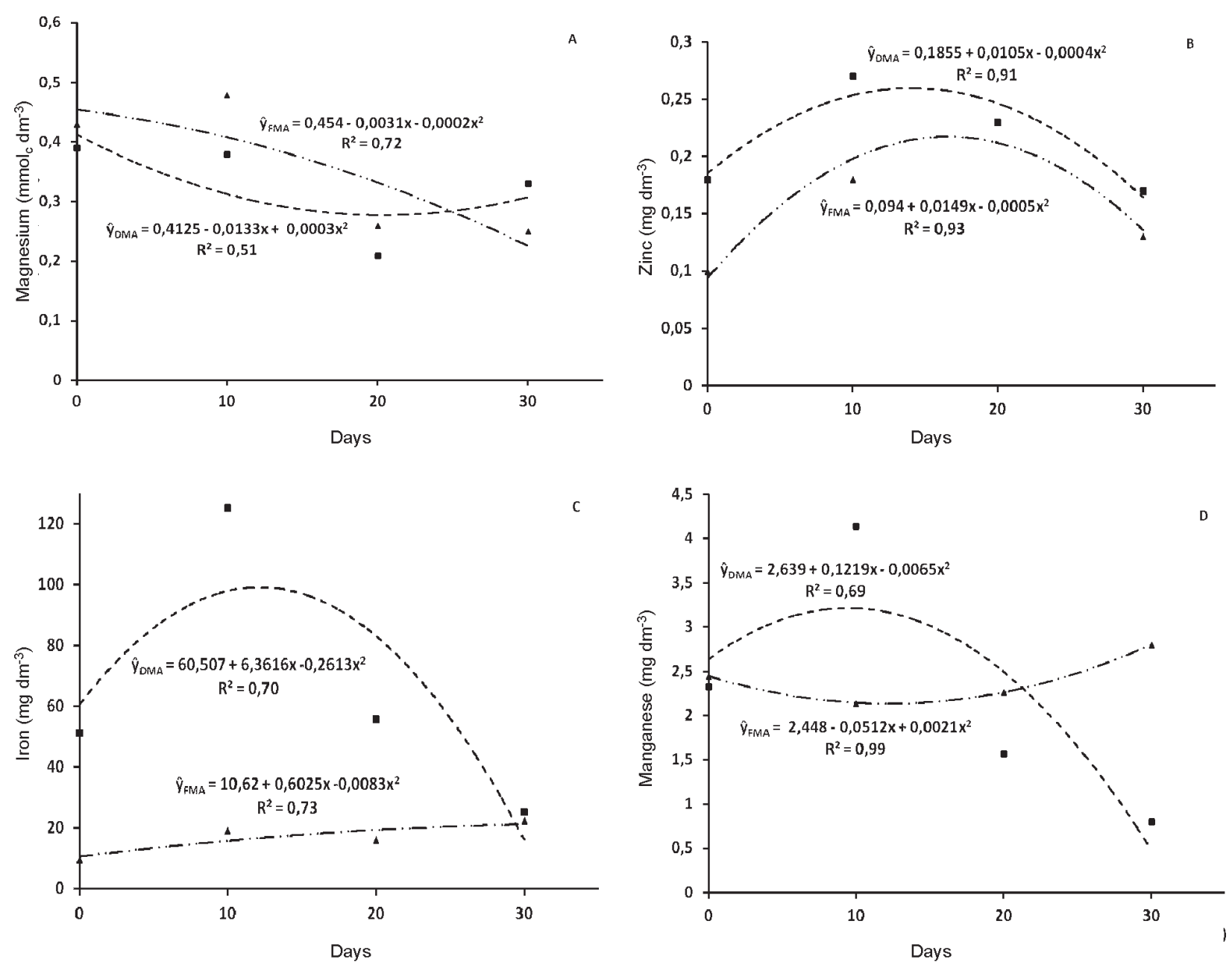

- DMA \& FMA

Figure 2. Variation in the contents of magnesium (A), zinc (B), iron (C) and manganese (D) over 30 days of solubilization trials of diabase (DMA) dust and phonolite dust (FMA) using Aspergillus niger in liquid culture medium.

concentration of the $\mathrm{C}$ source, $\mathrm{N}$ and phosphate limitation, $\mathrm{pH}$, aeration, concentration of trace elements and morphology of the producer organism). Among the metals that need to be in a limit amount are $\mathrm{Zn}, \mathrm{Mn}, \mathrm{Fe}$, $\mathrm{Cu}$, alkali metals and heavy metals (Papagianni, 2007). In the solubilization of silicates contained in rock dust, the concentrations of $\mathrm{Fe}$ and $\mathrm{Mn}$ in the medium decrease at first, possibly due to the formation of oxides and hydroxides of $\mathrm{Fe}$ and $\mathrm{Mn}$ with low solubility (Oliveira Junior et al., 2000; Mello \& Perez, 2009).

Plant ashes are two sources of potassium commonly used in organic agriculture, with about $10 \%$ of $\mathrm{K}$, and the decomposed cattle manure, with about $5 \%$ of $\mathrm{K}$ (Souza \& Alcântara, 2008). Thus, phonolite dust, with about $8 \%$ of $\mathrm{K}$, may be an alternative to organic fertilization. The biotechnology pathway by incubation of rock dust with $A$. niger and production of biofertilizer is a promising alternative in order to accelerate the release of nutrients.

\section{CONCLUSIONS}

The fungus Aspergillus niger promoted the solubilization of the elements contained in the dust of diabase and phonolite rocks.

The dust of the evaluated phonolite released soluble potassium in the culture medium in a significant way after 30 days of incubation.

Over the 30 days of trial, there were no significant variations in $\mathrm{pH}$ and exchangeable acidity in the performed treatments; however, there was effect on the levels of the soluble ions studied.

\section{AKNOWLEDGMENTS}

To the CNPq, for the scholarship granted to the first two authors and to FINEP for the financial support by the ROCKBIOCOM - Ref. Finep 0944/ 08 project. 


\section{REFERENCES}

ANDA - Associação Nacional para Difusão de Adubos (2014) Principais indicadores do setor de fertilizantes. Avaiable at: <http:// www.anda.org.br/estatisticas.aspx >. Accessed in May $20^{\text {th }}, 2014$.

Benites VM, Polidoro JC \& Resende AV (2010) Oportunidades para a inovação tecnológica no setor de fertilizantes no Brasil. Boletim Informativo da Sociedade Brasileira de Ciência do Solo, 35:18-21.

Brasil (1999) Ministério da Agricultura, Pecuária e Abastecimento. Instrução Normativa n ${ }^{\circ} 7$, de 17 de maio de 1999. Diário Oficial [da] República Federativa do Brasil. Brasília, DF, 19 de maio de 1999, Seção 1. 11p.

Carvalho W, Silva DDV, Canilha L \& Mancilha IM (2005) Aditivos alimentares produzidos por via fermentativa parte I: ácidos orgânicos. Revista Analytica, 18:70-76.

Ceccato SR (1989) Produção de biomassa e depuração biológica da vinhaça de cana de açúcar por cultura mista de fungos filamentosos e leveduras. Dissertação de Mestrado. Universidade Estadual Paulista, Rio Claro. 159p.

Cerezine PC, Nahas E \& Banzatto DA (1988) Phosphate accumulation by Aspergillus niger from fluorapatite. Applied Microbiology and Biotechnology, 29:501-505.

Curi N, Kämpf N \& Marques JJ (2005) Mineralogia e formas de potássio em solos brasileiros. In: Yamada T \& Roberts TL (Eds.) Potássio na agricultura brasileira. Piracicaba, POTAFOS. p.71-91.

FAO World Health Organization (2007) Guidelines for the production, processing, labelling and marketing of organically produced foods. Rome, FAO-WHO. 39p. (Codex Alimentarius. CAC/GL, 32).

Grimm LH, Kelly S, Krull R \& Hempel DC (2005) Morphology and productivity of filamentous fungi. Applied Microbiology and Biotechnology, 69:375-384.

Guebel DV \& Darias NVT (2001) Optimisation of citric acid production by $A$. niger through a metabolite flux balance model. Process Biotechnology, 4:01-11.

Hamdali H, Hafidi M, Virolle MJ \& Ouhdouch Y (2008) Rock phosphatesolubilizing actinomycetes: screening for plant growth-promoting activities. World Journal of Microbiology and Biotechnology, 24:25652575.

Kämpf N, Curi N \& Marques JJ (2009) Intemperismo e ocorrência de minerais no ambiente do solo. In: Melo, VF \& Alleoni LR (Eds.) Química e mineralogia do solo. Viçosa, SBCS. p.333-379.

Lian B, Wang B, Pan M, Liu C \& Teng HH (2008) Microbial release of potassium from K-bearing minerals by thermophilic fungus Aspergillus fumigates. Geochimica et Cosmochimica Acta, 72:87-98.

Lopes AS \& Guilherme LRG (2007) Fertilidade do Solo e Produtividade Agrícola. In: Novais RF, Alvarez V VH, Barros NF, Fontes RLF, Cantarutti RB, Neves JCL (Eds.) Fertilidade do Solo. Viçosa, SBCS. p.1-64.
Lopes-Assad ML, Rosa MM, Erler G \& Ceccato-Antonini SR (2006) Solubilização de pó-de-rocha por Aspergillus niger. Espaço \& Geografia, 9:1-17.

Lopes-Assad ML, Avansini SH, Rosa MM, Carvalho JRP \& CeccatoAntonini SR (2010) The solubilization of potassium-bearing rock powder by Aspergillus niger in small-scale batch fermentations. Canadian Journal of Microbiology, 56:598-605.

Machado FB, Nardy AJR, Melo RP, Oliveira MAF \& Squisato E (2005) As rochas intrusivas da formação Serra Geral na porção leste da bacia do Paraná no estado de São Paulo: aspectos petrográficos e geoquímicos - resultados preliminares. Geociências, 24:5-17.

Martins ES, Oliveira CG, Resende AV \& Matos MSF (2008) Agrominerais - Rochas Silicáticas como Fontes Minerais de Potássio para a Agricultura. In: Luz AB \& Lins FAF (Eds.) Rochas e Minerais Industriais: Usos e Especificações. Rio de Janeiro, CETEM. p.205-223.

Mehta KD, Chitrangada DAS \& Pandey BD (2010) Leaching of copper, nickel and cobalt from Indian Ocean manganese nodules by Aspergillus niger. Hydrometallurgy, 105:89-95.

Mello JWV de \& Perez DV (2009) Equilíbrio Químico das Reações no Solo. In: Melo V de F, Alleoni LRF (Eds.) Química e Mineralogia do Solo. Viçosa, SBCS. p.151-249.

Nascimento M \& Loureiro FEL (2009) O potássio na agricultura brasileira: fontes e rotas alternativas. In: Lapido-Loureiro FE, Melamed R, Neto JF (Eds.) Fertilizantes: agroindústria e sustentabilidade. Rio de Janeiro, CETEM. p.305-335.

Oliveira Junior JA de, Malavolta E \& Cabral CP (2000) Efeitos do manganês sobre a soja cultivada em solo de Cerrado do Triângulo Mineiro. Pesquisa Agropecuária Brasileira, 35:1629-1636.

Papagianni M (2007) Advances in citric acid fermentation by Aspergillus niger: biochemical aspects, membrane transport and modeling. Biotechnology Advances, 25:244-263.

Schuster E, Dunn-Coleman N, Frisvad JC \& Van Dijck PWM (2002) On the safety of Aspergillus niger - a review. Applied Microbiology and Biotechnology, 59:426-435.

Sheng XF (2005) Growth promotion and increased potassium uptake of cotton and rape by a potassium-releasing strain of Bacillus edaphicus. Soil Biology and Biochemistry, 37:1918-1922.

Souza RB de \& Alcântara FA (2008) Adubação no sistema organic de produção de hortaliças. Brasília, Embrapa Hortaliças. 8p. (Circular técnica, 65).

Sugumaran P \& Janarthanam B (2007) Solubilization of potassiumcontaining minerals by bacteria and their effect on plant growth. World Journal of Agricultural Sciences, 3:350-355.

Xiao CQ, Chi RA, Huang XH, Zhang WX, Qiu GZ \& Wang DZ (2008) Optimization for rock phosphate solubilization by phosphatesolubilizing fungi isolated from phosphate mines. Ecological Engineering, 33:187-193. 